http://nv.nltu.edu.ua

https://doi.org/10.15421/40280310

Article received $17.04 .2018 \mathrm{p}$.

Article accepted 26.04.2018 p.

ISSN 2519-2477 (online)

удк 630*56

$@$ Correspondence author

M. V. Mertsalo

myrvik@ukr.net

М. В. Мерцало

Національний лісотехнічний університет України, м. Львів, Україна

\title{
ДИНАМІКА І ПРОДУКТИВНІСТЬ СОСНОВИХ ДЕРЕВОСТАНІВ СУХОГО ЛИШАЙНИКОВОГО БОРУ В УМОВАХ ЗАХІДНОГО ПОЛІССЯ
}

За результатами аналізу структури лісового фонду Західного Полісся встановлено, що сухі бори у регіоні досліджень займають 13259,7 га, що становить 3,4 \% від площі вкритих лісовою рослинністю земель. Досліджено хід росту соснових деревостанів в умовах сухого бору, за висотою, діаметром, сумами площ перерізів, запасами та кількістю стовбурів, а також використано аналіз ходу росту модельних дерев різних вікових груп. Встановлено, що усі деревостани на пробних площах $\epsilon$ низькопродуктивними та належать до IV класу бонітету. Аналіз росту модельних дерев вказує на їх повільний ріст за висотою і діаметром. Встановлено, що кульмінація середнього і поточного приростів за висотою настає у віці 20-25 років, при цьому середній приріст за висотою не перевищує 0,25 м. Середні прирости за діаметром із зростанням віку збільшуються від 0,25 (20 років) до 0,27 см (60 років). Доведено, що середні прирости за висотою і діаметром сосни збільшуються у напрямку із заходу на схід регіону досліджень. Проаналізовано процеси зріджень деревостанів з віком та підтверджено його нерівномірний характер. У дослідних деревостанах 60-річного віку залишається не більше 13 \% дерев від початкової їх кількості. Використавши регресійні рівняння для математичного моделювання динаміки таксаційних показників 3 віком, розраховано фрагмент таблиці ходу росту соснових деревостанів IV класу бонітету в умовах Західного Полісся.

Ключові слова: сухі соснові бори; Cladonio-Pinetum Juraszek 1927; штучні соснові деревостани; хід росту сосни.

Вступ. Кліматичні та лісорослинні умови Західного Полісся сприяли формуванню різних за продуктивністю і складом соснових деревостанів. За даними ВО "Укрдержліспроект", у регіоні вони займають 64,8 \% від площі вкритих лісовою рослинністю земель. Це переважно чисті за складом середньоповнотні деревостани, які ростуть в умовах борів та суборів. На незначній площі лісового фонду (0,4 \%) сформувалися сухі сосново-лишайникові бори (Cladonio-Pinetum Juraszek 1927), зазвичай, у вкрай сухих та бідних лісорослинних умовах із дуже глибоким заляганням грунтових вод. Характерними ознаками таких деревостанів є їх низька продуктивність (IV, V класи бонітету) та добре розвинений мохово-лишайниковий ярус родів Сладонія і Цетраріа. Існують різні гіпотези щодо походження лишайникових борів Західного Полісся. Згідно 3 однією 3 них, лишайникові бори є природним різновидом сухого соснового бору, а за іншою - вони утворилися внаслідок заліснення земель після сільськогосподарського використання. Аналізуючи характеристики і сучасне поширення лишайникових борів, можна припустити, що обидві гіпотези мають своє підтвердження (Faltynowicz, 1986).

На сьогодні ріст і продуктивність соснових деревостанів у різних регіонах країни вивчені досить детально (Buzun, 1980; Lavrynenko \& Stopkan, 1960; Lytvak, 1968; Myakushko, 1978; Povarnitsyn, 1959). Результати проведених досліджень відображено у таблицях ходу росту нормальних і модальних деревостанів, природного та штучного походження (Shvydenko et al., 1986). Біль- шість досліджень проводили у панівних типах лісу, що мають важливе значення для організації ефективного лісовирощування. Натомість спеціальні дослідження росту і продуктивності низькобонітетних соснових деревостанів майже не проводили. Незважаючи на низьку продуктивність і товарність соснових деревостанів сухого лишайникового бору, вони є унікальними лісовими об'єктами, які потребують вивчення та охорони (Маkomaskiej-Juchiewicz \& Tworka, 2003).

Мета досліджень - проаналізувати динаміку росту і продуктивності штучних соснових деревостанів в умовах сухого лишайникового бору на території Західного Полісся.

Матеріали та методи дослідження. Щоб максимально охопити дослідженнями територію Західного Полісся, збір експериментальних даних проводили у східній, центральній та західній його частинах. Пробні площі (42 шт.) закладено у найтиповіших чистих соснових деревостанах штучного походження в умовах сухого бору. Деревостани на пробних площах належать до середньо- та високоповнотних, їх продуктивність відповідає IV класу бонітету, а вік становить $15-60$ років. На пробних площах здійснено весь комплекс лісівничотаксаційних досліджень відповідно до прийнятих у лісівництві та лісовій таксації методик. Аналіз росту та продуктивності деревостанів на пробних площах здійснювали за основними таксаційними показниками. Дослідні матеріали опрацьовано за допомогою системного аналізу та методів математичної статистики.

Інформація про автора:

Мерцало Мирослава Вікторівна, аспірант, кафедра ботаніки, деревинознавства та недеревних ресурсів лісу. Email: myrvik@ukr.net Цитування за ДСту: Мерцало М. В. Динаміка і продуктивність соснових деревостанів сухого лишайникового бору в умовах

Західного полісся. Науковий вісник НЛТУ України. 2018, т. 28, № 3. С. 48-51.

Citation APA: Mertsalo, M. V. (2018). Dynamics and Productivity of Scots Pine (Pinus Sylvestris I.) Stands of Dry Lichen-Pine Forests in

West Polissya. Scientific Bulletin of UNFU, 28(3), 48-51. https://doi.org/10.15421/40280310 
Результати дослідження. Динаміку росту та продуктивності соснових деревостанів в умовах сухого бору досліджено за результатами аналізу ходу росту деревостанів за висотою, діаметром, сумами площ перерізів, запасами та кількістю стовбурів, а також використано результати аналізу ходу росту модельних дерев різних вікових груп.

Для коректного порівняння таксаційних ознак насаджень у різні вікові періоди здійснено перевірку їх належності до одного природного ряду. Належність до одного природного ряду перевірено шляхом встановлення прямолінійних залежностей між віком і видовою висотою $(A H)$, віком і добутком віку на діаметр $(A D)$ та висотою і добутком другого коефіцієнта форми на висоту $\left(q_{2} H\right)$. Відхилення від вирівняних значень не перевищують допустимих величин і вказують на приналежність пробних площ до однієї лінії розвитку.

Зважаючи на бідні лісорослинні умови, соснові деревостани характеризуються низькою інтенсивністю росту дерев у висоту (рис. 1). Так, середня висота деревостану у віці 60 років становить тільки 12,6 м. Усі середні висоти деревостанів на пробних площах відповідають IV класові бонітету.

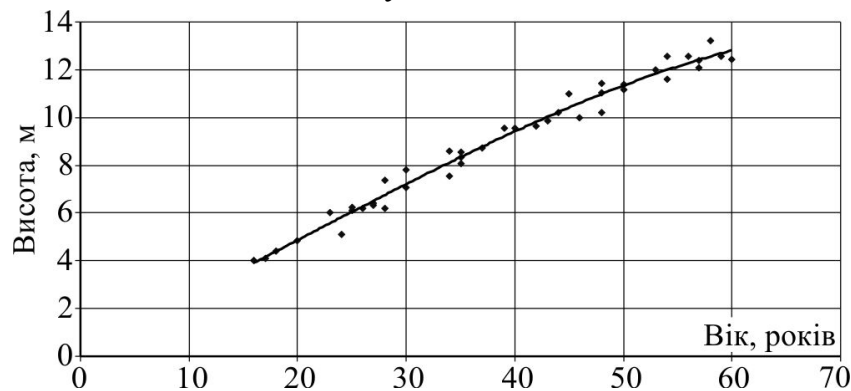

Рис. 1. Хід росту соснових деревостанів на пробних площах за висотою

Для встановлення зв'язку між віком $(A)$ і середніми висотами $(H)$ деревостанів на пробних площах, використано поліноміальне рівняння регресії третього порядку, яке характеризується високим значенням коефіцієнта детермінації $\left(R^{2}=0,981\right)$.

Порівнюючи значення середніх та верхніх висот дерев, встановлено, що з віком диференціація дерев за висотою у деревостанах зростає. Так, у деревостанах віком до 20 років різниця між середніми і верхніми висотами дерев становить 1,3-2,2 м, а у деревостанах віком 40-60 років вона зростає до 2,4-4,3 м. Така тенденція свідчить про зростання внутрішньовидової конкуренції за світло і мінеральні речовини у соснових деревостанах $з$ віком.

За результатами аналізу середніх висот соснових деревостанів залежно від місця розташування в регіоні досліджень з'ясовано, що середні висоти зростають у напрямку із заходу на схід незалежно від їх віку. Порівняно із західною частиною регіону середні висоти деревостанів у центральній частині вищі на 3-9 \%, а у східній - на 6-14\%. Інтенсивність росту сосни у висоту 3 віком, в умовах сухого лишайникового бору, майже не змінюється, а різниця між приростами у різні вікові періоди становить 4-12\%. Середній приріст деревостанів до 20 років становить $0,25^{ \pm 0,02} \mathrm{M}$, у деревостанах віком $21-40$ років $-0,24^{ \pm 0,04} \mathrm{M}$, та $0,22^{ \pm 0,03} \mathrm{M}-$ у деревостанах 41-60 років. Кульмінація середнього і поточного приростів за висотою настає у віці 20-25 років.
Лісорослинні умови впливають не тільки на ріст сосни за висотою, але й за діаметром також. Середні діаметри деревостанів на пробних площах змінюються від 3,1 до 16,3 см, залежно від їх віку. Величина середнього діаметра також зростає у напрямку із заходу на схід регіону досліджень, проте до 60-річного віку діаметри деревостанів на пробних площах у різних частинах регіону досліджень практично вирівнюються. Середні прирости за діаметром із зростанням віку збільшуються від 0,25 (20 років) до 0,27 см (60 років). Встановлені за результатами аналізу ходу росту модельних дерев коефіцієнти форми $\left(q_{2}\right)$ вказують на малу збіжність $\left(q_{2}=0,73-0,84\right)$ стовбу-рів дерев у деревостанах до 40 років та середню збіжність $\left(q_{2}=0,67-0,71\right)$ у деревостанах віком 40-60 років.

Зважаючи на відсутність природного поновлення сосни в умовах сухого бору, лісовідновлення здійснюють шляхом створення лісових культур. Переважно лісові культури садять із шириною міжрядь 1,5-2,0 м і відстанню в ряду $0,5-0,7 \mathrm{~m}$ із кількістю посадкових місць 8-10 тис. шт. на 1 га (Gordienko, Shlapak \& Goychuk et al., 2002). Незважаючи на високу початкову кількість дерев у деревостанах, через екстремальні умови існування відбувається іх інтенсивне зрідження (рис. 2).

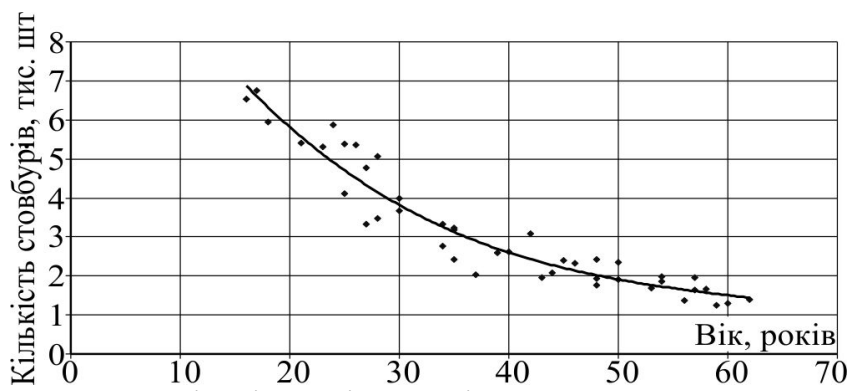

Рис. 2. Динаміка кількості стовбурів дерев у соснових деревостанах сухого соснового бору

Встановлено, що у деревостанах до 20 років у середньому залишається до $64 \%$ дерев від початкової їх кількості. 3 віком інтенсивність зріджування внаслідок природних причин та господарської діяльності зростає та у насадженнях віком 20-40 років залишається 20$54 \%$ дерев. На кінець дослідного періоду інтенсивність зрідження дещо знижується і у 60-річних деревостанах залишається до $13 \%$ дерев. На інтенсивність зрідження деревостанів істотний вплив має зростання диференціації дерев за висотою із зростанням віку. Найчастіше відсталі у рості за висотою дерева всихають, такі процеси властиві як поодиноким деревам, так і дрібним групам (3-5 дерев). Для більшості деревостанів старшого віку характерним $€$ біогрупове розміщення дерев, незважаючи на їх штучне походження.

Аналіз росту і продуктивності соснових деревостанів в умовах сухого бору передбачав встановлення залежностей між таксаційними ознаками деревостанів і їх віком. Для апроксимації рядів розподілу даних використано поліноміальні рівняння регресії другого i третього порядків. Отримані коефіцієнти рівнянь наведені у табл. 1.

Використані математичні функції для апроксимації таксаційних показників вказують на високу достовірність економетричної моделі за відносно низьких значень середньої похибки. Загалом статистичні показники регресійних рівнянь вказують на їх високу адекватність 
при встановленні змін таксаційних показників соснових деревостанів.

Використавши регресійні рівняння для математичного моделювання динаміки таксаційних показників з віком, розраховано фрагмент таблиці ходу росту модальних соснових деревостанів IV класу бонітету в умовах Західного Полісся (табл. 2).

Табл. 1. Коефіціснти рівнянь регресії залежності між віком і таксаційними ознаками деревостанів

\begin{tabular}{|c|c|c|c|c|c|}
\hline \multirow{2}{*}{ Таксаційний показник } & \multicolumn{3}{|c|}{ Значення коефіцієнтів рівнянь } & \multirow{2}{*}{$R^{2}$} \\
\cline { 2 - 5 } & $a_{0}$ & $a_{1}$ & $a_{2}$ & $a_{3}$ & 0,00002 \\
\hline Середня висота, м & 0,0941 & 0,22325 & 0,00112 & $-0,00002$ \\
\hline Середній діаметр, см & $-5,76083$ & 0,54684 & $-0,00311$ & - & 0,961 \\
\hline Сума площ перерізів, ${ }^{2} / г \mathrm{a}$ & $-8,1048969$ & 1,1762822 & $-0,0094277$ & $-0,0000001$ & 0,911 \\
\hline Кількість дерев, тис. шт./га & 13,0386 & 0,49376 & 0,00741 & $-0,00004$ & 0,919 \\
\hline Запас, м ${ }^{3} /$ га & $-67,7702$ & 5,77695 & 0,01549 & $-0,00026$ & 0,940 \\
\hline
\end{tabular}

Табл. 2. Хід росту модальних соснових деревостанів в умовах сухого сосново-лишайникового бору Західного Полісся

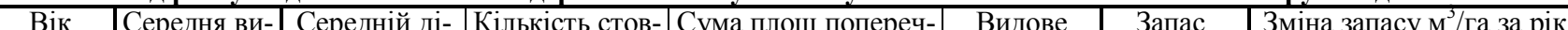

\begin{tabular}{|c|c|c|c|c|c|c|c|c|}
\hline & & & & & & & & \\
\hline роки & сота, м & аметр, см & бурів, шт./га & них перерізів, м²/га & число & $\mathrm{m}^{3} / г \mathrm{a}$ & середня & поточна \\
\hline 15 & 3,5 & 3,1 & 7165 & 7,21 & 0,887 & 19 & 1,28 & - \\
\hline 20 & 4,8 & 4,9 & 5809 & 11,69 & 0,807 & 43 & 2,14 & 4,71 \\
\hline 25 & 6,1 & 6,5 & 4704 & 15,55 & 0,694 & 65 & 2,59 & 4,38 \\
\hline 30 & 7,2 & 8,1 & 3820 & 18,86 & 0,623 & 85 & 2,83 & 4,05 \\
\hline 35 & 8,4 & 9,5 & 3128 & 21,65 & 0,574 & 104 & 2,96 & 3,72 \\
\hline 40 & 9,4 & 11,0 & 2598 & 23,99 & 0,538 & 121 & 3,01 & 3,40 \\
\hline 45 & 10,4 & 12,3 & 2199 & 25,93 & 0,511 & 136 & 3,02 & 3,07 \\
\hline 50 & 11,3 & 13,7 & 1903 & 27,52 & 0,490 & 150 & 2,99 & 2,74 \\
\hline 55 & 12,1 & 15,0 & 1678 & 28,81 & 0,474 & 162 & 2,94 & 2,41 \\
\hline 60 & 12,9 & 16,3 & 1495 & 29,86 & 0,460 & 172 & 2,87 & 2,08 \\
\hline
\end{tabular}

Складений фрагмент таблиці ходу росту відображає ріст модальних чистих соснових деревостанів штучного походження в умовах сухого соснового бору (рис. 3). На жаль, у літературних джерелах не вдалось знайти таблиці ходу росту соснових деревостанів в умовах сухих лишайникових борів для порівняння запасів, тому використано таблиці ходу росту нормальних (Shvydenko, Savich, Strochinsky et al., 1986) та модальних (Lakyda, 2012; Baghinsky, 2015) соснових деревостанів.

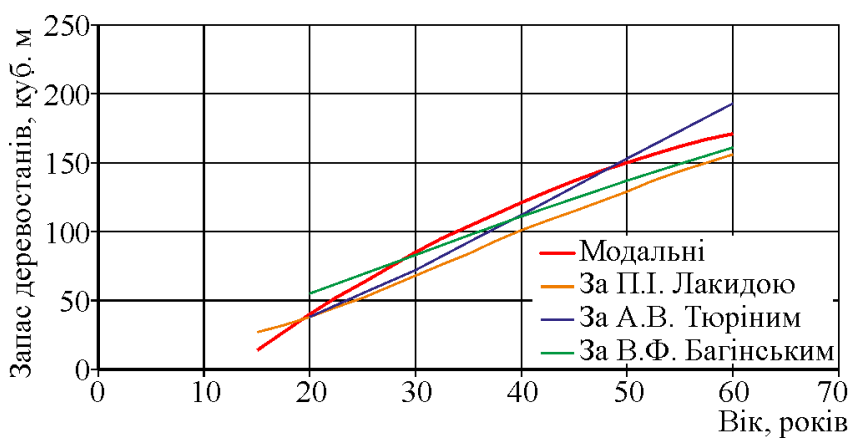

Рис. 3. Хід росту соснових деревостанів IV класу бонітету

Порівняння запасів модальних соснових деревостанів із запасами з інших таблиць ходу росту є не зовсім коректним, оскільки вони складені для інших регіонів та типів лісу. Використання наявних нормативів під час лісоінвентаризаційних робіт, зазвичай, призведе до заниження реальної продуктивності соснових деревостанів в умовах сухого бору із домінуванням лишайникового вкриття.

Висновки. Чисті соснові деревостани штучного походження, що ростуть в умовах сухого соснового бору на території Західного Полісся, характеризуються слабким ростом сосни за висотою і діаметром, а їх продуктивність відповідає IV класові бонітету.

Середній приріст за висотою не перевищує 0,25 м/рік незалежно від віку і може використовуватись як діагностична ознака під час таксації соснових деревостанів в умовах сухого соснового бору. Встановлено, що середні висоти деревостанів одного віку зростають (до 14 \%) із заходу на схід у регіоні досліджень. 3 віком середній приріст соснових деревостанів за діаметром збільшується, проте не перевищує $0,27 \mathrm{~cm} /$ рік. Модельні дерева віком до 40 років характеризуються малою збіжністю стовбурів, а старші - середньою.

У соснових деревостанах сухого бору відбувається інтенсивне та нерівномірне за площею зрідження 3 віком. Так, у 60-річних деревостанах залишається не більше $13 \%$ дерев від початкової їх кількості. Зважаючи на значну диференціацію дерев за віком і висотою, доцільно використовувати комбінований метод проведення доглядових рубань, особливо під час прочищень та проріджень.

Сухі сосново-лишайникові бори є об'єктом охорони у країнах Європейського Союзу та України, як рідкісні та унікальні природні об'єкти. Зважаючи на їх низьку продуктивність та незначну площу, яку вони займають, ведення господарства у таких лісах повинно грунтуватись не на лісосировинних, а на природоохоронних засадах.

\section{Перелік використаних джерел}

Baginskii, V. F. (2015). Dinamika i produktivnosts modalınykh sosnovykh drevostoev v Belorusskom Polesьe. [Dynamics and productivity of modal Scots pine stands in the Belorussian Polesie]. Eko-potentcial, 3(11), 14-23. [In Russian].

Buzun, V. A. (1980). Produktivnostь sosnovykh nasadzhenii v Ukrainskom Polesse. [Productivity of pine plantations in Ukrainian Polesia]. Lesnoe khozyaistvo, 1, 25-27. [In Russian].

Faltynowicz, W. (1986). The dynamics and role of lichens in managed Cladonia-Scotch pine forest (Cladonio-Pinetum), Vol. 69. Warshawa: Monogr. Bot. 96 p.

Hordiienko, M. I., Shlapak, V. P., \& Hoichuk, A. F., et al. (2002). Kultury sosny zvychainoi v Ukraini. [Forest artificial of Scots pine in Ukraine]. Kyiv: In-t ahrar. ekonomiky UAAN. 872 p. [In Ukrainian]

Lakyda, P. I. (2012). Shtuchni sosnovi derevostany Polissia Ukrainyprohnoz rostu ta produktyvnosti. [Artificial pine forest stands of Polissya of Ukraine - forecast of growth and productivity]. KorsunShevchenkivskyi: FOP Maidachenko I. S. 171 p. [In Ukrainian].

Lavrynenko, D. D., \& Stopkan, V. V. (1960). Naukovi osnovy pidvyshchennia produktyvnosti lisiv Polissia Ukrainskoi RSR. [Scientific fundamentals of productivity increase forests of the Polissya of the Ukrainian SSR]. Kyiv: USHA. 196 r. [In Ukrainian]. 
Litvak, P. V. (1968). Osobennosti rosta sosny obyknovennoi v razlichnykh gigrotopakh Polesia USSR. [Peculiarities of the growth of Scots pine in various hygrotops of the Polesye of the USSR]. Lesovodstvo i agrolesomelioratciia, 15, 104-110. [In Russian].

Makomaskiej-Juchiewicz, M., \& Tworka, S. (2003). Ekologiczna sieć Natura 2000: problem czy szansa. [Ecological Natura 2000 network: a problem or an opportunity.] Krakow: Instytut Ochrony Przyrody PAN. 237 p. [In Polish]

Miakushko, V. K. (1978). Sosnovye lesa ravninnoi chasti USSR: Geobotan. kharakteristika i pervich. biol. produktivnost. [Pine forests of the plain part of the USSR: Geobotan. characteristic and primary. Biol. productivity]. Kyiv: Nauk. dumka. 255 p. [In Russian].

Povarnitsyn, V. O. (1959). Lisy Ukrainskoho Polissia. [Forests of Ukrainian Polissya]. Kyiv: Vyd-vo AN URSR. 208 p. [In Ukrainian].

Shvidenko, A. S., Savich, Iu. N., Strochinskii, A. A., et al. (1987). Normativno-spravochnye materialy dlia taksatcii lesov Ukrainy $i$ Moldavii. [Normative reference materials for taxing the forests of Ukraine and Moldova]. Kyiv: Urozhai. 559 p. [In Russian].

М. В. Мерцало
Национальный лесотехнический университет Украины, г. Львов, Украина

ДИНАМИКА И ПРОИЗВОДИТЕЛЬНОСТЬ СОСНОВЫХ ДРЕВОСТОЕВ СУХОГО ЛИШАЙНИКОВОГО БОРА В УСЛОВИЯХ ЗАПАДНОГО ПОЛЕСЬЯ

По результатам анализа структуры лесного фонда Западного Полесья установлено, что сухие боры в регионе исследований занимают 13259,7 га, что составляет 3,4 \% от покрытой лесом площади. Исследованы ход роста и производительность сосновых древостоев в условиях сухого бора, по высоте, диаметру, суммам площадей сечений, запасам и количеству стволов, а также использованы результаты анализов хода роста модельных деревьев различных возрастных групп. Установлено, что все древостои на пробных площадях имеют низкую производительность и относятся к IV классу бонитета. Анализ роста модельных деревьев указывает на их медленный рост по высоте и диаметру. Установлено, что кульминация среднего и текущего приростов по высоте наступает в возрасте 20-25 лет, при этом средний прирост по высоте не превышает 0,25 м. Средние приросты по диаметру с ростом возраста увеличиваются от 0,25 (20 лет) до 0,27 см (60 лет). Доказано, что средние приросты по высоте и диаметру сосны растут в направлении с запада на восток региона исследований. Проанализированы процессы изреживания древостоев с возрастом и установлен его неравномерный характер. В исследуемых древостоях 60-летнего возраста остается не более $13 \%$ деревьев от начального их количества. Использовав регрессионные уравнения для математического моделирования динамики таксационных показателей с возрастом, рассчитан фрагмент таблицы хода роста сосновых древостоев IV класса бонитета в условиях Западного Полесья

Ключевые слова: сухие сосновые боры; Cladonio-Pinetum Juraszek 1927; искусственные сосновые древостои; ход роста сосны.

M. V. Mertsalo

Ukrainian National Forestry University, Lviv, Ukraine

\section{DYNAMICS AND PRODUCTIVITY OF SCOTS PINE (PINUS SYLVESTRIS L.) STANDS OF DRY LICHEN-PINE FORESTS IN WEST POLISSYA}

Growing conditions of West Polissya are favourable for Scots pine forests that differ from each other in terms of their growth rates and composition. Pine forests occupy there up to $64.8 \%$ of the forest lands. Only a small share ( $0.4 \%$ of the total forest area) is covered with the artificially regenerated, poor, slowly growing forests that resemble a dry lichen-pine forest (Cladonio-Pinetum Juraszek 1927) association. The purpose of our research was to analyse the growth rate in such pine stands occurring on the territory of West Polissya. In the most typical pure pine stands of the artificial origin, of age ranging from 15 to 60 years, 42 sample plots were established. Growth and productivity of pine stands were studied based on the results of the analysis of the growth rate in stands concerning height, diameter (dbh), and basal area. Besides, the volume increment was measured in the selected model trees. The pine stands studied are characterized by the low growth rates in height; the average height of the tree stands at the age of 60 is only $12.6 \mathrm{~m}$. The average annual height increment in stands of up to 20 years old is as low as $0.25^{ \pm 0.02} \mathrm{~m}$, and it is even lower $\left(0.22^{ \pm 0.03} \mathrm{~m}\right)$ in the 41-60 year old stands. The culmination of the average and current height increment takes place at the age of 20-25 years. The average $\mathrm{dbh}$ of the tree stands described varies from $3.1 \mathrm{~cm}$ to $16.3 \mathrm{~cm}$ depending on their age. The average dbh annual increment in 20 year old stands is as low as $0.25 \mathrm{~cm}$, while it is a little bit higher $(0.27 \mathrm{~cm})$ in stands that are 60 years old. Despite the high initial number of trees (8-10 thousand specimens/ha), a typical for such growing conditions very low survival rate results in substantial reduction of the stands stocking, down to some 13 per cent of the above number of trees/ha in the 60 year old stands. The intensive decrease of the stands stocking with its increasing age is strongly affected by the stepwise increasing differentiation in height between individual trees. Using the regression equations for mathematical modeling of the dynamics of taxation indicators with age, a fragment of the growth rate table in pine stands of the 4th class site index in the conditions of West Polissya was calculated. Since they are both rare and unique, the lichen forests are protected. Given their low productivity and the small area that they occupy, management in such forests should be based not on commercial, but on environmental principles.

Keywords: dry pine forests; Cladonio-Pinetum Juraszek 1927; artificial pine stands; pine growth rate. 